\title{
Structural Hurdles to Large-Scale Forest Restoration in the Brazilian Amazon
}

\author{
Markus Gastauer*, Rosane Barbosa Lopes Cavalcante, Cecílio Frois Caldeira and \\ Samia de Socorro Nunes \\ Instituto Tecnológico Vale, Belém, Brazil
}

Keywords: sustainable land use, diversified agriculture, payments for ecosystem services, native species, species selection, environmental monitoring

\section{INTRODUCTION}

Since August 2019, pictures of Amazonia in flames have received global attention and drawn the attention of international media, governments and nongovernmental organizations (NGOs) toward exponentially increasing deforestation rates, highlighting the need for innovations for sustainable development of the region to mitigate global climate crises and threats to biodiversity (Lovejoy and Nobre, 2019). The scientific community claims that for Amazonia 4.0, i.e., an emerging bioeconomy valuing biodiversity by aggregating new technologies and possibilities such as cyber-physical systems, internet of things, communication networks and artificial intelligence with the socioenvironmental resources of the Amazon region, large-scale forest restoration is required to prevent the world's largest tropical forest from collapsing (Levis et al., 2020). More

\section{OPEN ACCESS}

Edited by:

Nadia S. Santini,

National Autonomous University of

Mexico, Mexico

Reviewed by:

Rachael Helene Nolan,

Western Sydney University, Australia

*Correspondence:

Markus Gastauer

markus.gastauer@itv.org

Specialty section:

This article was submitted to

Conservation and Restoration

Ecology,

a section of the journal

Frontiers in Ecology and Evolution

Received: 10 August 2020

Accepted: 17 September 2020

Published: 29 October 2020

Citation:

Gastauer M, Cavalcante RBL, Caldeira CF and Nunes SdS (2020) Structural Hurdles to Large-Scale Forest Restoration in the Brazilian Amazon. Front. Ecol. Evol. 8:593557.

doi: 10.3389/fevo.2020.593557 than $60 \%$ of the Amazonia rainforest is contained within Brazil; thus, the country plays a key role in this biome's future.

The forest landscape restoration concept extends beyond pure ecological restoration, i.e., the restitution of biodiversity and ecosystem structure and functioning to original, old-growth forest levels (Mansourian et al., 2017), to include agroforestry systems, tree plantations and further initiatives to restitute the forest canopy (Stanturf et al., 2014) aiming to link ecological needs to enhance biodiversity and ecosystem services with the economic demands of local communities and land owners (Celentano et al., 2017; Urzedo et al., 2020a). Although carbon sequestration is often the primary driver of contemporary forest restoration (Griscom et al., 2020), further co-benefits emerge for air purification, water management, biodiversity and income possibilities, especially when native species are used (Lewis et al., 2019; Nunes et al., 2020). Income possibilities refer to income generated through supply chains, payments for ecosystem services (PES), and the trade of products from agroforestry systems. By integrating and amplifying the number of trees in gardens, farms or forests, these silvicultural activities aim to reverse soil and land degradation, increasing the productivity and functionality of the entire landscape (Besseau et al., 2018). Given these multiple benefits, forest landscape restoration initiatives have been frequently included in corporate sustainability strategies to achieve carbon neutrality and demonstrate social and environmental commitment (Seymour, 2020).

Despite the recognition of socioeconomic and environmental benefits, global movements to valorize restoration as part of climate change mitigation activities and successful implementation of small- to medium-scale forest restoration projects (Rodrigues et al., 2019), the Amazonian forest cover has steadily declined, and forest restoration is restricted to single initiatives. Weak governance is considered one of the underlying reasons, but a set of technical and socioeconomic issues further impede large-scale restoration in the Amazon. In addition to noncompliance of rural properties with environmental legislation, labor and capital-intensive forest implementation, insufficiently structured markets for diversified silviculture, knowledge gaps and logistic difficulties represent further forest restoration barriers in the Amazon 
(Nunes et al., 2020) (Figure 1). Here, we address these structural hurdles to overcome challenges and achieve large-scale forest restoration in the Brazilian Amazon.

\section{STIMULATING LEGAL COMPLIANCE OF RURAL PROPERTIES}

Private rural properties account for 53\% of the entire Brazilian territory (Soares-Filho et al., 2014), most of it within properties larger than 1.500 ha (Costa et al., 2018), highlighting their importance for the protection of biotic resources. Environmental legislation in the Brazilian Amazon (Federal Law 12,651/2012, known as the Brazilian Forest Code) includes two main instruments to protect native vegetation in private rural properties: permanent preservation areas (APPs, in Portuguese) and Legal Reserves (RLs, in Portuguese). APPs include ecologically sensitive riparian vegetation, springs, steep slopes or hilltops where only low-impact activities such as ecotourism are allowed. The forest restoration obligation for APPs depends on the type of APP and features such as river width and property size. In RLs, which are designed to promote the sustainable use of timber and non-timber forest resources, the forest canopy must be maintained. RLs account for $80 \%$ of the Amazonian property area, but forest restoration may be required in only $50 \%$ of the property area if certain conditions are met or even less for small properties. Despite past incentives for environmental regularization, e.g., programs established by the International Climate Fund, the German Development Bank (KfW) or the
Responsible Soy Project by The Nature Conservancy and Cargill (Jung et al., 2017), these thresholds are rarely achieved (Nunes et al., 2019) because the ecological benefits of compliance do not outweigh the economic benefits of non-compliance (Stickler et al., 2013). Thus, further market and government pressures (Pacheco et al., 2017) or facilitation of the regularization process (Amaral et al., 2017) are necessary to achieve legal compliance and enable large-scale forest restoration, e.g., on low-productivity stands to maintain the profitability of rural properties (Strassburg et al., 2014).

\section{KNOWLEDGE GAPS IN RESTORATION PRACTICES}

\section{Restoration Strategies}

Depending on socioeconomic circumstances, land-use history and landscape context, forest restoration may be achieved by natural regeneration after removal of degrading agents, the installation of agroforestry systems bridging ecological and economic needs for sustainable development, and active restoration by seeding or seedling planting (Brancalion et al., 2016; Souza et al., 2016). Additionally, assisted natural regeneration with less inference, such as enrichment planting or the control of invasive grasses, may represent viable solutions in some cases (Crouzeilles et al., 2020).

The choice of a suitable restoration strategy directly influences the costs of the project and depends on the level and history of degradation and the amount and quality of the remaining

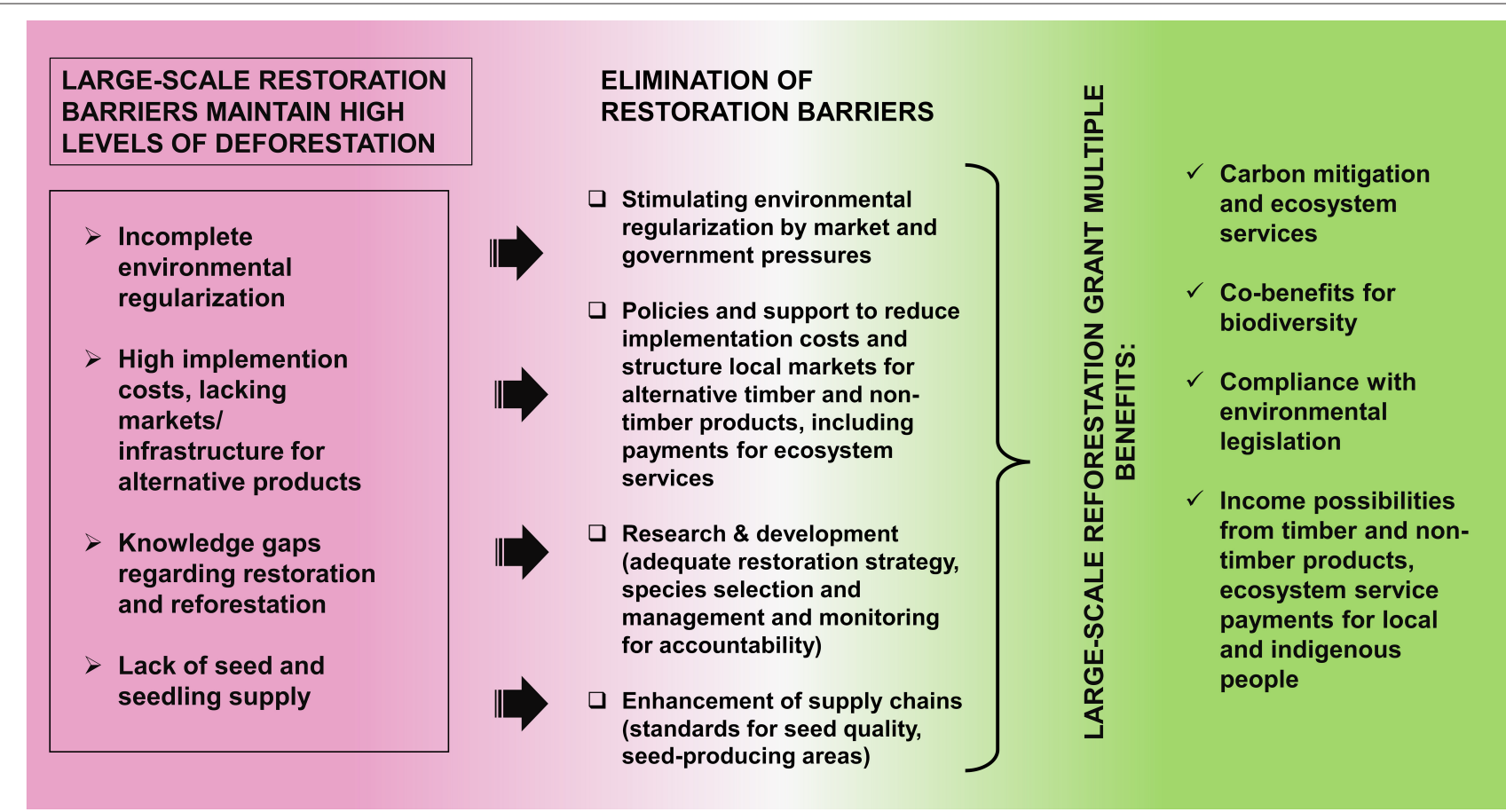

FIGURE 1 | The elimination of restoration barriers enables society to take advantage of multiple benefits resulting from reduced deforestation rates and increasing forest cover. 
forest cover. Natural regeneration is successful in the Amazon when the remaining forest cover exceeds 50\% (Brancalion et al., 2016). Landscapes and regions with higher deforestation rates may show lower natural regeneration potential, requiring active restoration approaches such as direct seeding or seedling plantation techniques. A recent biome-wide estimate indicated that only $39 \%$ of deforested areas in the Brazilian Amazon show high potential for natural regeneration (Vieira et al., 2017), indicating that more than the half of the biome's logged area may be unable to recover naturally. As the natural regeneration potential may vary as a function of the local or regional context, e.g., the presence of smaller, well-conserved, diverse forest remnants may outweigh the importance of larger, degraded or less diverse secondary forests, the development of methodologies by which the actual potential for natural regeneration in relation to the local or regional context can be detected is paramount for efficient forest restoration (Carvalho Ribeiro et al., 2020).

\section{Species Selection and Management}

The success of active restoration strategies depends on the use of species with specific adaptations to local environmental constraints, including edaphic, actual and expected future climate conditions (Zwiener et al., 2017). To date, more than 10,000 native tree species in the Amazon have already been described (Ter Steege et al., 2019), many of which can be applied for active forest restoration. Principles of functional and phylogenetic ecology may guide the identification of promising tree species for forest restoration activities aiming to compensate for or mitigate environmental impacts considering site-specific climatic or edaphic constraints (Thomas et al., 2017; Laughlin et al., 2018) but require detailed knowledge about species' ecological niches and adaptations to restore functional, resilient forests (Gastauer et al., 2020a).

The cultivation of native species for economic purposes, e.g., agroforestry systems or further commercial plantations, requires the selection of species able to provide yields, subsistence and income. Many Amazonia tree species provide timber and nontimber products that may be used as fuel, fiber, and food or in the pharmaceutical or cosmetic industry, and reintroduction of traditional knowledge regarding their potential may increase the diversity of farms and gardens (Caballero-Serrano et al., 2019). Nevertheless, low degrees of domestication and a lack of experience with the cultivation of native species result in preferences for exotic species in many cases (Rolim et al., 2019). The seed quality of most native seeds, for example, is limited by their irregular development patterns, short harvest periods and rapid dispersal (Hay and Probert, 2013), challenging the establishment of promising species in the field. Moreover, seed dormancy, i.e., evolutionary adaptations that prevent seeds from germinating under unsuitable ecological conditions, delays germination and seedling production. Species with seeds that are sensitive to desiccation (recalcitrant seeds) remain a significant challenge in terms of storage (Umarani et al., 2015). Thus, research regarding the propagation of native species (seed harvesting, processing and storage, seedlings and vegetative propagation) and plantation management (nutritional demands, plant health, ecophysiology, plantation designs and thinning) as well as innovations and development of new biodiversity-derived products are necessary to explore the economic potential of the biome's diversity and achieve large-scale forest restoration in the Amazon.

\section{Monitoring Restoration Success}

Monitoring is necessary to evaluate the success of forest restoration activities, especially when regenerating forests are used to achieve corporate carbon neutrality or fulfill national or international environmental commitments. A range of indicators, such as the amount and monetary value of sequestered carbon, the number of created jobs, realized trainings, costs related to implementation and net gains of incomes and subsistence, are available to measure socioeconomic restoration outcomes. Environmental assessments necessary to measure the success of ecological restoration efforts should include the evaluation of the vegetation structure, biodiversity measures and ecological processes such as the return of productivity, nutrient cycling, and water management (Gastauer et al., 2020b).

Currently, environmental assessments are generally carried out through time- and money-consuming field surveys, challenging the large-scale monitoring of restoration projects, especially in remote areas. In contrast, low costs and high degrees of automatization for repeated measures covering large spatial scales qualify remote-sensing techniques for this purpose. During the last decade, considerable advances have been achieved in detecting biomass (important to account for sequestered carbon), levels of biodiversity and the successional advance of regeneration forests, but validation by ground data remains the limiting factor (Chave et al., 2019). Innovative approaches that simplify or automate this validation open new avenues for expanding our capacity to assess restoration performances over unprecedented spatial and temporal scales using satellites (Almeida et al., 2020).

\section{SOCIOECONOMIC CONSTRAINTS IMPEDE THE DIVERSIFICATION OF AMAZONIAN FORESTRY}

\section{Implementation Costs}

Restoration costs depend strongly on the restoration strategy, and the benefits can outweigh the implementation expenses. An increase in the restoration project size reduces the cost per unit area, simultaneously increasing the biodiversity benefits by reducing the edge effects (Strassburg et al., 2019). Nevertheless, high implementation costs remain major barriers to forest restoration by local communities without access to credit (Saraiva et al., 2020).

Thus, strong partnerships between local people, governments and/or the private sector are required to implement restoration activities and their long-term management. In this context, the inclusion of large-scale forest restoration activities in corporate carbon neutrality (Smith, 2020; Vale, 2020) and further sustainability strategies are promising 
approaches to overcome implementation difficulties (Seymour, 2020).

\section{Income Opportunities and Their Constraints}

Forest landscape restoration may benefit rural development by increasing family incomes, employment opportunities, and community resilience, although success may depend on governance and land tenure systems (Adams et al., 2016; Erbaugh and Oldekop, 2018). Worldwide, the economic benefits of restored forests are estimated to be between 0.7 and 9 trillion dollars (Verdone and Seidl, 2017). In association with 1,000 hectares of reforested land in the Brazilian Atlantic Forest, up to 200 jobs may be created, including jobs related to seed collection, seedling production, planting, maintenance, and downstream manufacturing of timber and nontimber products (Calmon et al., 2011), as well as emerging opportunities from biodiversity-derived innovations. Additionally, PES, including those related to carbon sequestration or water production, can encourage forest restoration and provide economic and social benefits (Grima et al., 2016).

In the Amazon, this potential may not be completely realized because restoration activities compete with less sustainable landuse practices, principally cattle ranching and soy production (Jusys, 2016; Lathuillière et al., 2017), and lacking markets and value chains for alternative products handicap the diversification of the rural economy (Stabile et al., 2020). Well-structured markets are required for PES, as the measurement and monetary valorization of environmental benefits involving different stakeholders with different perceptions are not easy tasks. However, important instruments such as Reducing Emissions from Deforestation and Forest Degradation (REDD+) and Clean Development Mechanisms (CDM) are not sufficiently regulated in most Brazilian Amazonian states. Thus, the systematic structuring of alternative markets for timber and nontimber products and the roll-out of PES schemes are necessary to enlarge income opportunities and economic viability of largescale restoration programs in the Brazilian Amazon.

\section{LIMITED SEED AND SEEDLING SUPPLIES AS A MAJOR LOGISTIC BOTTLENECK IN LARGE-SCALE RESTORATION}

The success of active forest restoration projects depends on the availability and quality of seeds or seedlings of native species, which are currently difficult to obtain. According to a recent estimate, the number of seedlings necessary to actively restore actual vegetation deficits in the Itacaiunas watershed only (1.25 $\mathrm{Mkm}^{2}$ ) surpasses twice the capacity of tree nurseries in the entire Brazilian Amazon (Nunes et al., 2020). The demand for native seeds for seedling production or direct seeding techniques far exceeds the capacity of harvesting from the wild (Broadhurst et al., 2016), requiring the establishment of seed production areas to satisfy the demand. Seed networks linking seed collectors and producers from local communities with organizations and seed buyers are a promising strategy for upscaling the offered native seeds for large-scale restoration programs but require capacity building, flexibilization of actual seed regulations, and diversification of the seed market (Urzedo et al., 2020b).

\section{CONCLUSION}

Contrary to pure ecological restoration, the forest landscape restoration approach postulates that integrating different levels of forest restoration can generate multiple socioeconomic benefits that may outcompete traditional, less sustainable landforms in the long term. Despite the recognition of this potential, large-scale restoration initiatives are still challenged by knowledge gaps, insufficient supplies of seeds and seedlings, a lack of incentives, and socioeconomic constraints such as high implementation costs and competition with lesssustainable forms of land use (Figure 1). To realize the potential related to large-scale forest restoration in the Brazilian Amazon, it is thus necessary to establish and enhance the entire restoration value chain, ranging from the availability of seeds and seedlings to the processing and commercialization of timber and nontimber products. Effective monitoring systems are required to detect deviations from desired restoration trajectories and highlight the need for intervention. Governments, NGOs and the private sector should work together to (i) stimulate the environmental regularization of rural properties; (ii) close knowledge gaps through specific public or private requests for research and development; (iii) engage local communities and implement effective financial mechanisms and policies, i.e., structured markets for PES and certified timber or nontimber products, to diversify Amazonian forestry and agriculture; and (iv) create incentives to enhance the seed and seedling supply to support restoration activities using native species (Figure 1). Concentrated actions on these topics may reduce deforestation rates and encourage large-scale forest restoration to prevent the biome from collapsing.

\section{AUTHOR CONTRIBUTIONS}

SN and MG designed this study. MG wrote the paper with important contributions from RC (restoration strategies, seed, and seedling supply) and CC (species selection and management). All authors contributed to the article and approved the submitted version.

\section{FUNDING}

This article was funded by the project Recomposição Florestal (\#RBRS000603.90) from Instituto Tecnológico Vale. 


\section{REFERENCES}

Adams, C., Rodrigues, S. T., Calmon, M., and Kumar, C. (2016). Impacts of largescale forest restoration on socioeconomic status and local livelihoods: what we know and do not know. Biotropica 48, 731-744. doi: 10.1111/btp.12385

Almeida, D. R. A., Stark, S. C., Valbuena, R., Broadbent, E. N., Silva, T. S. F., de Resende, A. F., et al. (2020). A new era in forest restoration monitoring. Restor. Ecol. 28, 8-11. doi: 10.1111/rec.13067

Amaral, P., Reis, T., and Giudice, R. (2017). Assessing Compliance With the Forest Code: A Practical Guide. Brasília: Instituto B. Available online at: https://www.bvrio.org/view?type=publicacao\&key=publicacoes/d50f7d4d201f-4881-9ec5-ca8f6a84bdaf.pdf (accessed September 07, 2020).

Besseau, P., Graham, S., and Christophersen, T. (2018). Restoring Forests and Landscapes: The Key to a Sustainable Future. Vienna: Global Partnership on Forest and Landscape Restoration.

Brancalion, P. H. S., Schweizer, D., Gaudare, U., Mangueira, J. R., Lamonato, F., Farah, F. T., et al. (2016). Balancing economic costs and ecological outcomes of passive and active restoration in agricultural landscapes: the case of Brazil. Biotropica 48, 856-867. doi: 10.1111/btp.12383

Broadhurst, L. M., Jones, T. A., Smith, F. S., North, T., and Guja, L. (2016). Maximizing seed resources for restoration in an uncertain future. Bioscience 66, 73-79. doi: 10.1093/biosci/biv155

Caballero-Serrano, V., McLaren, B., Carrasco, J. C., Alday, J. G., Fiallos, L., Amigo, J., et al. (2019). Traditional ecological knowledge and medicinal plant diversity in Ecuadorian Amazon home gardens. Glob. Ecol. Conserv. 17:e00524. doi: 10.1016/j.gecco.2019.e00524

Calmon, M., Brancalion, P. H. S., Paese, A., Aronson, J., Castro, P., da Silva, S. C., et al. (2011). Emerging threats and opportunities for large-scale ecological restoration in the Atlantic forest of Brazil. Restor. Ecol. 19, 154-158. doi: 10.1111/j.1526-100X.2011.00772.x

Carvalho Ribeiro, S. M., Rajão, R., Nunes, F., Assis, D., Neto, J. A., Marcolino, C., et al. (2020). A spatially explicit index for mapping Forest Restoration Vocation (FRV) at the landscape scale: application in the Rio Doce basin, Brazil. Sci. Total Environ. 744:140647. doi: 10.1016/j.scitotenv.2020.140647

Celentano, D., Rousseau, G. X., Muniz, F. H., van Varga, I. D., Martinez, C., et al. (2017). Towards zero deforestation and forest restoration in the Amazon region of Maranhão state, Brazil. Land Use Policy 68, 692-698. doi: 10.1016/j.landusepol.2017.07.041

Chave, J., Davies, S. J., Phillips, O. L., Lewis, S. L., Sist, P., Schepaschenko, D., et al. (2019). Ground data are essential for biomass remote sensing missions. Surv. Geophys. 40, 863-880. doi: 10.1007/s10712-019-09528-w

Costa, M. A., Rajão, R., Stabile, M. C. C., Azevedo, A. A., and Correa, J. (2018). Epidemiologically inspired approaches to land-use policy evaluation: the influence of the rural environmental registry (car) on deforestation in the Brazilian Amazon. Elem. Sci. Anth. 6, 1. doi: 10.1525/elementa.260

Crouzeilles, R., Beyer, H. L., Monteiro, L. M., Feltran-Barbieri, R., Pessôa, A. C. M., Barros, F. S. M., et al. (2020). Achieving cost effective landscape scale forest restoration through targeted natural regeneration. Conserv. Lett. 13:e12709. doi: $10.1111 /$ conl.12709

Erbaugh, J. T., and Oldekop, J. A. (2018). Forest landscape restoration for livelihoods and well-being. Curr. Opin. Environ. Sustain. 32, 76-83. doi: 10.1016/j.cosust.2018.05.007

Gastauer, M., Caldeira, C. F., Ramos, S. J., Trevelin, L. C., Jaffé, R., Oliveira, G., et al. (2020a). Integrating environmental variables by multivariate ordination enables the reliable estimation of mineland rehabilitation status. J. Environ. Manage. 256:109894. doi: 10.1016/j.jenvman.2019.109894

Gastauer, M., Sarmento, P. S. M., Santos, V. C. A., Caldeira, C. F., Ramos, S. J., Teodoro, G. S., et al. (2020b). Vegetative functional traits guide plant species selection for initial mineland rehabilitation. Ecol. Eng. 148, 1057-1063. doi: 10.1016/j.ecoleng.2020.105763

Grima, N., Singh, S. J., Smetschka, B., and Ringhofer, L. (2016). Payment for ecosystem services (PES) in Latin America: analysing the performance of 40 case studies. Ecosyst. Serv. 17, 24-32. doi: 10.1016/j.ecoser.2015. 11.010

Griscom, B. W., Busch, J., Cook-Patton, S. C., Ellis, P. W., Funk, J., Leavitt, S. M., et al. (2020). National mitigation potential from natural climate solutions in the tropics. Philos. Trans. R. Soc. Lond. B Biol. Sci. 375:20190126. doi: 10.1098/rstb.2019.0126
Hay, F. R., and Probert, R. J. (2013). Advances in seed conservation of wild plant species: a review of recent research. Conserv. Physiol. 1:cot030. doi: $10.1093 /$ conphys/cot030

Jung, S., Rasmussen, L. V., Watkins, C., Newton, P., and Agrawal, A. (2017). Brazil's national environmental registry of rural properties: implications for livelihoods. Ecol. Econ. 136, 53-61. doi: 10.1016/j.ecolecon.2017.02.004

Jusys, T. (2016). Fundamental causes and spatial heterogeneity of deforestation in Legal Amazon. Appl. Geogr. 75, 188-199. doi: 10.1016/j.apgeog.2016.08.015

Lathuillière, M. J., Miranda, E. J., Bulle, C., Couto, E. G., and Johnson, M. S. (2017). Land occupation and transformation impacts of soybean production in Southern Amazonia, Brazil. J. Clean. Prod. 149, 680-689. doi: 10.1016/j.jclepro.2017.02.120

Laughlin, D. C., Chalmandrier, L., Joshi, C., Renton, M., Dwyer, J. M., and Funk, J. L. (2018). Generating species assemblages for restoration and experimentation: a new method that can simultaneously converge on average trait values and maximize functional diversity. Methods Ecol. Evol. 9, 1764-1771. doi: 10.1111/2041-210X.13023

Levis, C., Flores, B. M., Mazzochini, G. G., Manhães, A. P., Campos-Silva, J. V., Borges de Amorim, P., et al. (2020). Help restore Brazil's governance of globally important ecosystem services. Nat. Ecol. Evol. 4, 172-173. doi: 10.1038/s41559-019-1093-x

Lewis, S. L., Wheeler, C. E., Mitchard, E. T. A., and Koch, A. (2019). Restoring natural forests is the best way to remove atmospheric carbon. Nature 568, 25-28. doi: 10.1038/d41586-019-01026-8

Lovejoy, T. E., and Nobre, C. (2019). Amazon tipping point: last chance for action. Sci. Adv. 5:eaba2949. doi: 10.1126/sciadv.aba2949

Mansourian, S., Stanturf, J. A., Derkyi, M. A. A., and Engel, V. L. (2017). Forest landscape restoration: increasing the positive impacts of forest restoration or simply the area under tree cover?: Quality or quantity in forest landscape restoration? Restor. Ecol. 25, 178-183. doi: 10.1111/rec.12489

Nunes, S., Barlow, J., Gardner, T., Sales, M., Monteiro, D., and Souza, C. (2019). Uncertainties in assessing the extent and legal compliance status of riparian forests in the eastern Brazilian Amazon. Land Use Policy 82, 37-47. doi: 10.1016/j.landusepol.2018.11.051

Nunes, S., Gastauer, M., Cavalcante, R. L., Ramos, S. J., Caldeira, C. F., Silva, D., et al. (2020). Challenges and opportunities for large-scale reforestation in the Eastern Amazon using native species. For. Ecol. Manage. 466:118120. doi: 10.1016/j.foreco.2020.118120

Pacheco, R., Rajão, R., Soares-Filho, B., and van der Hoff, R. (2017). Regularization of legal reserve debts: perceptions of rural producers in the state of Pará and Mato Grosso in Brazil. Ambient. Soc. 20, 181-200. doi: 10.1590/1809-4422asoc0012r1v2022017

Rodrigues, S. B., Freitas, M. G., Campos-Filho, E. M., do Carmo, G. H. P., da Veiga, J. M., Junqueira, R. G. P., et al. (2019). Direct seeded and colonizing species guarantee successful early restoration of South Amazon forests. For. Ecol. Manage. 451:117559. doi: 10.1016/j.foreco.2019.117559

Rolim, S. G., Piña-Rodrigues, F. C. M., Batista, A., Freitas, M. L. M., Brienza Junior, S., Zakia, M. J. B., et al. (2019). Research Gaps and Priorities in Silviculture of Native Species in Brazil. Available online at: https://wribrasil.org. br/pt/publicacoes (accessed September 07, 2020).

Saraiva, M., Ferreira, M. D. P., da Cunha, D. A., Daniel, L. P., Homma, A. K. O., and Pires, G. F. (2020). Forest regeneration in the Brazilian Amazon: public policies and economic conditions. J. Clean. Prod. 269:122424. doi: 10.1016/j.jclepro.2020.122424

Seymour, F. (2020). Seeing the forests as well as the (trillion) trees in corporate climate strategies. One Earth 2, 390-393. doi: 10.1016/j.oneear.2020.05.006

Smith, B. (2020). Microsoft Will Be Carbon Negative by 2030. Official Microsoft Blog. Available online at: https://blogs.microsoft.com/blog/2020/01/16/microsoftwill-be-carbon-negative-by-2030/ (accessed August 4, 2020).

Soares-Filho, B., Rajão, R., Macedo, M., Carneiro, A., Costa, W., Coe, M., et al. (2014). Land use. Cracking Brazil's forest code. Science. 344, 363-364. doi: 10.1126/science. 1246663

Souza, S. E. X. F., Vidal, E., Chagas, G., de, F., Elgar, A. T., and Brancalion, P. H. S. (2016). Ecological outcomes and livelihood benefits of communitymanaged agroforests and second growth forests in Southeast Brazil. Biotropica 48, 868-881. doi: 10.1111/btp. 12388

Stabile, M. C. C., Guimarães, A. L., Silva, D. S., Ribeiro, V., Macedo, M. N., Coe, M. T., et al. (2020). Solving Brazil's land use puzzle: increasing 
production and slowing Amazon deforestation. Land Use Policy 91:104362. doi: 10.1016/j.landusepol.2019.104362

Stanturf, J. A., Palik, B. J., and Dumroese, R. K. (2014). Contemporary forest restoration: a review emphasizing function. For. Ecol. Manage. 331, 292-323. doi: 10.1016/j.foreco.2014.07.029

Stickler, C. M., Nepstad, D. C., Azevedo, A. A., and McGrath, D. G. (2013). Defending public interests in private lands: compliance, costs and potential environmental consequences of the Brazilian Forest Code in Mato Grosso. Philos. Trans. R. Soc. Lond. B Biol. Sci. 368:20120160. doi: 10.1098/rstb.2012.0160

Strassburg, B. B. N., Beyer, H. L., Crouzeilles, R., Iribarrem, A., Barros, F., de Siqueira, M. F., et al. (2019). Strategic approaches to restoring ecosystems can triple conservation gains and halve costs. Nat. Ecol. Evol. 3, 62-70. doi: 10.1038/s41559-018-0743-8

Strassburg, B. B. N., Latawiec, A. E., Barioni, L. G., Nobre, C. A., da Silva, V. P., Valentim, J. F., et al. (2014). When enough should be enough: improving the use of current agricultural lands could meet production demands and spare natural habitats in Brazil. Glob. Environ. Change 28, 84-97. doi: 10.1016/j.gloenvcha.2014.06.001

Ter Steege, H., Mota de Oliveira, S., Pitman, N. C. A., Sabatier, D., Antonelli, A., Guevara Andino, J. E., et al. (2019). Towards a dynamic list of Amazonian tree species. Sci. Rep. 9:3501. doi: 10.1038/s41598-019-40101-y

Thomas, E., Alcázar Caicedo, C., Moscoso, L. G., Vásquez, A., Osorio, L. F., Salgado-Negret, B., et al. (2017). The Importance of Species Selection and Seed Sourcing in Forest Restoration for Enhancing Adaptive Capacity to Climate Change: Colombian Tropical Dry Forest as a Model. Convention on Biological Diversity. Available online at: http://repository.humboldt.org.co/handle/20. 500.11761/34077 (accessed September 14, 2020).

Umarani, R., Aadhavan, E. K., and Faisal, M. M. (2015). Understanding poor storage potential of recalcitrant seeds. Curr. Sci. 108, 2023-2034. doi: 10.18520/CS/V108/I11/2023-2034
Urzedo, D. I., de Piña-Rodrigues, F. C. M., Feltran-Barbieri, R., Junqueira, R. G. P., and Fisher, R. (2020b). Seed networks for upscaling forest landscape restoration: is it possible to expand native plant sources in Brazil? For. Trees Livelihoods 11:259. doi: 10.3390/f11030259

Urzedo, D. I., Neilson, J., Fisher, R., and Junqueira, R. G. P. (2020a). A global production network for ecosystem services: the emergent governance of landscape restoration in the Brazilian Amazon. Glob. Environ. Change 61:102059. doi: 10.1016/j.gloenvcha.2020.102059

Vale (2020). Carbon Neutral. Available online at: http://www.vale.com/brasil/EN/ sustainability/Pages/carbonneutral.aspx (accessed August 4, 2020).

Verdone, M., and Seidl, A. (2017). Time, space, place, and the Bonn Challenge global forest restoration target. Restor. Ecol. 25, 903-911. doi: 10.1111/rec.12512

Vieira, I., Ferreira, J., Salomão, R., Brienza Júnior, S., Matsumoto, M., and Braga, J. (2017). Potencial de regeneração natural da vegetação na Amazônia. Brasília: MMA.

Zwiener, V. P., Padial, A. A., Marques, M. C. M., Faleiro, F. V., Loyola, R., and Peterson, A. T. (2017). Planning for conservation and restoration under climate and land use change in the Brazilian Atlantic Forest. Divers. Distrib. 23, 955-966. doi: 10.1111/ddi.12588

Conflict of Interest: The authors declare that the research was conducted in the absence of any commercial or financial relationships that could be construed as a potential conflict of interest.

Copyright (C) 2020 Gastauer, Cavalcante, Caldeira and Nunes. This is an open-access article distributed under the terms of the Creative Commons Attribution License (CC $B Y)$. The use, distribution or reproduction in other forums is permitted, provided the original author(s) and the copyright owner(s) are credited and that the original publication in this journal is cited, in accordance with accepted academic practice. No use, distribution or reproduction is permitted which does not comply with these terms. 